\title{
Abundance of food plant species and food habits of Rhinoceros unicornis Linn. in Pobitora Wildlife Sanctuary, Assam, India
}

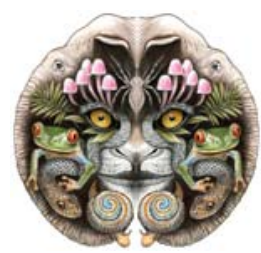

\author{
Pradip Konwar ${ }^{1}$, Malabika Kakati Saikia ${ }^{2}$ \& P.K. Saikia ${ }^{3}$ \\ ${ }^{1}$ Research Scholar, ${ }^{2}$ Guest Faculty, ${ }^{3}$ Reader, Department of Zoology, Gauhati University, Guwahati-781 014, Assam, India \\ Email: ${ }^{3}$ saikiapk@ rediffmail.com (corresponding author)
}

Date of publication (online): 26 September 2009 Date of publication (print): 26 September 2009 ISSN 0974-7907 (online) | 0974-7893 (print)

Editor: L.A.K. Singh

\section{Manuscript details:}

Ms \# 01640

Received 05 September 2006

Final received 17 September 2007

Finally accepted 31 August 2009

Citation: Konwar, P., M.K. Saikia \& P.K. Saikia (2009). Abundance of food plant species and food habits of Rhinoceros unicornis Linn. in Pobitora Wildlife Sanctuary, Assam, India. Journal of Threatened Taxa 1(9): 457-460.

Copyright: () Pradip Konwar, Malabika Kakati Saikia \& P.K. Saikia 2009. Creative Commons Attribution 3.0 Unported License. JoTT allows unrestricted use of this article in any medium for non-profit purposes, reproduction and distribution by providing adequate credit to the authors and the source of publication.

Author Details: All the authors specialized in animal ecology and wildlife biology. PRADIP Konwar is a research scholar. His field of Interest is the wildlife biology and conservation works of mammalian fauna in Assam.

MALABIKA KaKatI SAIKIA teaches the specialized student of animal ecology and wildlife biology. She has obtained her PhD degree on butterfly diversity and ecology and specializes in butterfly taxonomy, wildlife biology and biodiversity conservation

P.K. SAIKIA is in charge of animal ecology and wildlife biology special branch of the University. His field of specialization is wildlife biology and wildlife conservation, ornithology and biodiversity conservation including butterflies.

Author Contribution: All three authors conducted field surveys at Pobitora WLS but most of the surveys were done by P. Konwar; M.K. Saikia and P.K. Saikia wrote the paper.

Acknowledgement: The authors are grateful to the Chief Conservator of Forest, Government of Assam, for providing permission to conduct field work at Pobitora Wildlife Sanctuary; to the range officer, forest guards, mahout, and other forest officials of PWS for their continuous support during the survey; and to the surrounding villagers of PWS for their generosity with information during the study.
Abstract: Food habits and abundance of food plant species of Rhinoceros unicornis in Pobitora Wildlife Sanctuary were studied from January 1999 through December 2001. Totally 32 numbers of Rhino food plants were identified, of which 15 were grasses, four shrubs, five aquatic hydrophytes and eight tree species (21 terrestrial and 11 aquatic). During the dry season, the Rhino feeds on almost $90 \%$ food items from Hemarthria compressa, Arundo donax, Phragmites karka, Cerex rubro-brumee etc. The other short grasses such as Cynodon dactylon, Andropogon ssp., Cenchrus ciliaris, Chrysopogon aciculatus and tender and young shoots and twigs of Schelristechya fuesche, Saccharum spontaneum, Lagerstroemia flosreginae etc. are consumed in limited portions. The rhino consumes 11 cultivated crops and vegetables, viz., Ricinus communis, Oryza sativa, Solanum melongena, Lycopersicon esculentum, Solanum tuberosum, Brassica nigra, Luffa cylindrica, Luffa acutangula, Cucurbita moschata, Cucumis sativus and Ipomoea batatas etc. Highest density of food plant species observed in the study area were Cynodon dactylon $\left(167.5 / \mathrm{m}^{2}\right)$, Hemarthria compressa $\left(73.75 / \mathrm{m}^{2}\right)$, Vetiveria zizanioides $\left(56 / \mathrm{m}^{2}\right)$, Saccharum ravannae $\left(51.5 / \mathrm{m}^{2}\right)$, Pharagmites karka $\left(50.75 / \mathrm{m}^{2}\right)$, Leersia hexandra $\left(46.75 / \mathrm{m}^{2}\right)$, Brachiarea pseudointerrupta $\left(40 / \mathrm{m}^{2}\right)$ and Eichhornia crassipes $\left(35 / \mathrm{m}^{2}\right)$.

Keywords: Food habit, food-plant status, Pobitora Wildlife Sanctuary, Rhinoceros unicornis, Rhino.

\section{INTRODUCTION}

This study is on the food habits of the Indian Rhinoceros Rhinoceros unicornis and the status of food plant species in Pobitora Wildlife Sanctuary (PWS), which holds the second largest concentration of rhinos in Assam. As per 1999 census in Assam, there were about 1800 Rhinoceros unicornis out of which 1771 were distributed in three protected areas, viz., Kaziranga National Park (1649), Orang National Park (46), and Pobitora Wildlife Sanctuary (76). The rhinos have disappeared from the other previously known sites in Assam.

\section{Study Area}

Pobitora Wildlife Sanctuary is located between $26^{\circ} 12^{\prime}-26^{\circ} 15^{\prime} \mathrm{N} \& 92^{\circ} 02^{\prime}-92^{\circ} \mathrm{O} 5^{\prime} \mathrm{E}$ and $50 \mathrm{~km}$ east of Guwahati City on the south bank of the river Brahmaputra within Morigoan District of Assam. Although PWS is the smallest (only $38.83 \mathrm{~km}^{2}$ ), it supports the highest density of rhinos in comparison to other areas of Assam. The population census indicated the presence of 54 rhinos in 1987, 56 in 1993, 58 in 1995 and 76 in 1999. The unit density of rhino in PWS is $4.62 / \mathrm{km}^{2}$, whereas it is $3.60 / \mathrm{km}^{2}$ in Kaziranga National Park.

Pobitora Wildlife Sanctuary was a grazing reserve for cattle before 1971. During that time a few rhinos strayed out of Lawkhowa and Orang wildlife sanctuaries and gradually became resident. Two such grazing reserves comprising $38.83 \mathrm{~km}^{2}$ were declared as reserve forests in 1971. In 1987, Pobitora was declared a wildlife sanctuary covering an area of $16 \mathrm{~km}^{2}$. Presently the sanctuary is surrounded by 20 villages, the farmlands of which are frequented by rhinos. Although, a proper study of habitat characteristics of PWS is yet to be done, the gross constituents are $80 \%$ grassland, $18 \%$ woodland and only $1 \%$ wetland. According to Islam \& Rahmani (2004), and Talukdar (1996), forestland covers only $2 \%$, thatch with Albizia regeneration 8\%, pure thatch 40\%, thatch with Phragmites karka and Arundo donax etc. $20 \%$ and perennial waterlogged area $5 \%$ and swampy area $25.5 \%$.

The climate is subtropical moist with average maximum temperature $38^{\circ} \mathrm{C}$ and minimum $9^{\circ} \mathrm{C}$, humidity ranges between $75 \%$ and $95 \%$. Rainfall occurs throughout the year and annual rainfall is $3000 \mathrm{~mm}$. Maximum rainfall is during the months of July \& August and the driest month is January. 
Table 1. List of natural food plant species of rhinos in Pobitora Wildlife Sanctuary

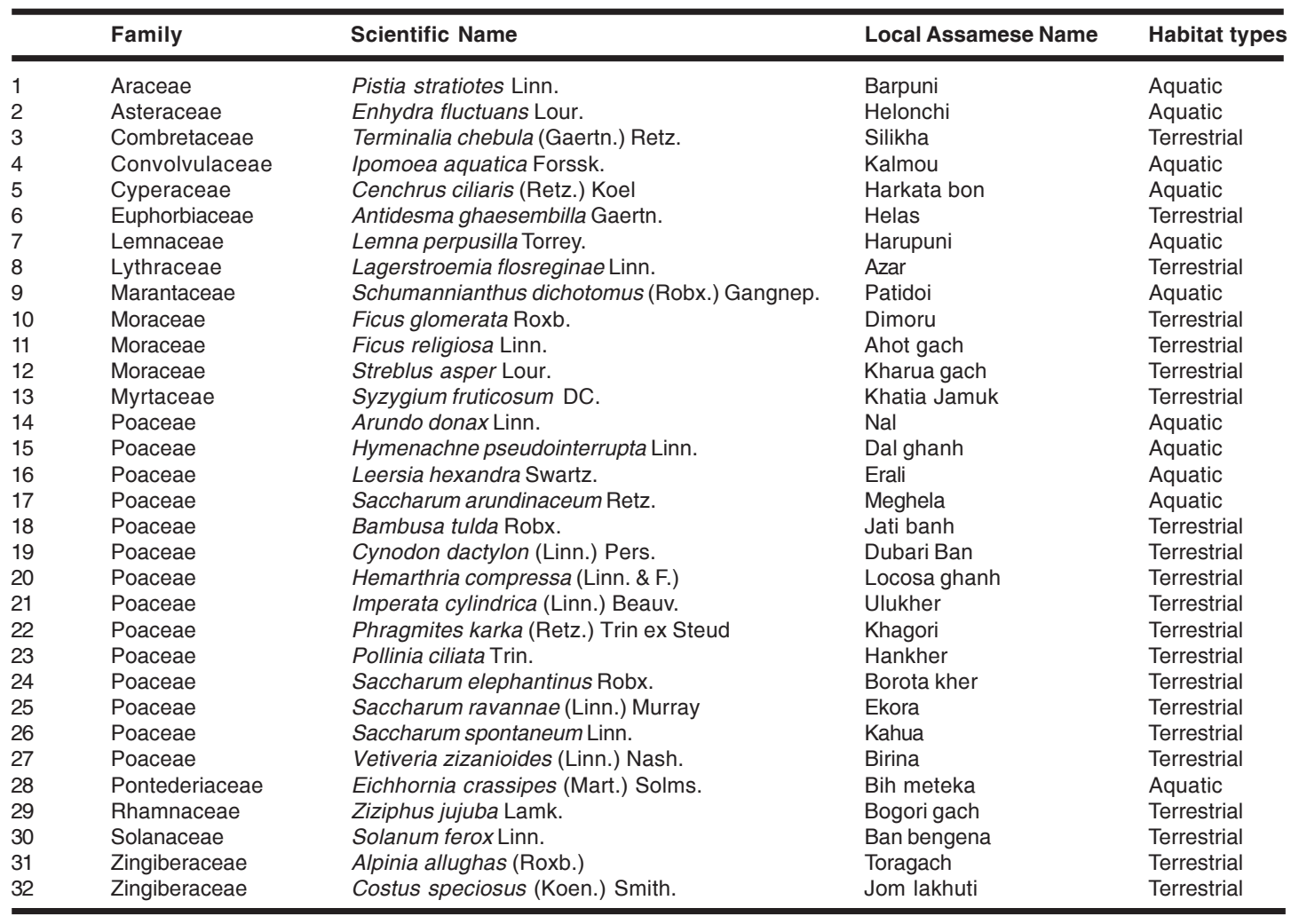

Table 2. List of cultivated food plant species consumed by rhinos in Pobitora Wildlife Sanctuary

\begin{tabular}{llll}
\hline & Family & English / Local Assamese Name & Scientific Name \\
\hline 1 & Brassicaceae & Mustard plant / Hariah & Brassica nigra (Linn.) Koch. \\
2 & Convolvolaceae & Mitha alu / Ronga alu & Ipomoea batatas (Linn.) Lamk. \\
3 & Cucurbitaceae & Cucumber / Tioh & Cucumis sativus Linn. \\
4 & Cucurbitaceae & Pumkin / Rangalaw & Cucurbita moschata (Duch. \& Lam) Desh. Ex. Poir. \\
5 & Cucurbitaceae & Jika & Luffa acutangula (Linn.) Roxb. \\
6 & Cucurbitaceae & Bhol & Luffa cylindrica (Linn.) M. Roem. \\
7 & Euphorbiaceae & Castor plant / Ara goch & Ricinus communis Linn. \\
8 & Poaceae & Rice / Dhan & Oryza sativa Linn. \\
9 & Solanaceae & Tomato / Bilahi & Lycopersicon esculentum Mill. \\
10 & Solanaceae & Brinjal / Bengena & Solanum melongena Linn. \\
11 & Solanaceae & Potato / Alu & Solanum tuberosum Linn.
\end{tabular}

\section{Methods}

The study was carried out from January 1999 to December 2001. Various methods were applied for collecting the food habit data of $R$. unicornis and distribution status and abundance of food plant species in PWS. The methods were: (A) Food habits of rhino by direct observation and sampling of freshly deposited rhino dung-pile; and (B) Status and abundance of food plants in the study site.

\section{A. Food habits of rhinos a. Direct observation}

(i) Natural plants: To identify the food habits of rhinos in PWS, sites were monitored extensively from elephant back and the data of food plant species of rhinos were collected by the methods of Wallmo et al. (1973), Neff (1974), and Riney (1982). Apart from direct sighting of food plant species consumed, the browsing plant species were collected and identified in the field and laboratory. Herbarium sheets were prepared for reference and confirmation of identification of food plant species with Kanjilal et al. (1934, 1936, 1938, 1939), Kanjilal (1940), and Kanjilal \& Bor (1940).

(ii) Cultivated food plants: During the survey, forest personnel, elephant mahouts and elderly persons from the village were interviewed to understand the overall cultivated food plant species consumed by the rhinos.

b. Sampling rhino dung-pile: As the consumed food plant materials were not completely digested this method was used to identify the food items, at least up to the generic level. Fresh faecal matter of rhinos was collected from dung heaps, washed with tap water, sieved and analysed as per methods of Korschgen (1980), Holechek et al. (1982), and Cooperrider (1986).

\section{B. Status and abundance of Food plants}

To estimate frequency, density and abundance of food plant species, 50 stratified quadrates of size $1 \times 1 \mathrm{~m}$ were laid 
Table 3. Distribution status of terrestrial grasses and trees consumed as food by rhinos in Pobitora Wildlife Sanctuary

\begin{tabular}{llccc}
\hline & Scientific Name & Frequency (\%) & Density / $\mathbf{~}^{2}$ & Abundance \\
\hline 1 & Cynodon dactylon & 70 & 167.50 & 239.28 \\
2 & Saccharum ravannae & 30 & 51.50 & 171.66 \\
3 & Phragmites karka & 30 & 50.75 & 169.16 \\
4 & Hemarthria compressa & 47 & 73.75 & 163.88 \\
5 & Imperata cylindrical & 25 & 39.50 & 158.00 \\
6 & Vetiveria zizanioides & 40 & 56.00 & 140.00 \\
7 & Pollinia ciliata & 5 & 5.00 & 100.00 \\
8 & Saccharum spontaneum & 5 & 5.00 & 100.00 \\
9 & Costus speciosus & 10 & 3.25 & 32.50 \\
10 & Sachumannianthus dichotomous & 5 & 1.50 & 30.00 \\
11 & Alpinia allughas & 15 & 2.35 & 15.66 \\
12 & Lagerstroemia flosreginae & 5 & 0.05 & 1.00 \\
13 & Solanum ferox & 5 & 0.05 & 1.00 \\
14 & Ziziphus jujuba & 5 & 0.05 & 1.00 \\
\hline
\end{tabular}

Table 4. Distribution status of aquatic vegetation consumed as food by rhinos in Pobitora Wildlife Sanctuary

\begin{tabular}{llccc}
\hline & Scientific Name & Frequency (\%) & Density / $\mathbf{~}^{2}$ & Abundance \\
\hline 1 & Arundo donax & 5 & 25.00 & 500.00 \\
2 & Eichhornia crassipes & 10 & 35.00 & 350.00 \\
3 & Leersia hexandra & 15 & 46.75 & 311.66 \\
4 & Lemna perpusilla & 5 & 15.00 & 300.00 \\
5 & Hymenachnepseudointerrupta & 15 & 40.00 & 266.66 \\
6 & Pistia stratiotes & 5 & 10.00 & 200.00 \\
7 & Ipomoea aquatica & 15 & 15.00 & 100.00 \\
8 & Cenchrus ciliaris & 15 & 9.25 & 61.66 \\
9 & Enhydra fluctuans & 5 & 2.50 & 50.00 \\
\hline
\end{tabular}

randomly in PWS. In all the successive quadrates, each plant species was separately counted. Herbarium sheets for particular plants were prepared only once even if they occurred in more than one quadrate. The required parameters were estimated with the formulae used by Krebs (1985), Arumugam (1998), and Southwood \& Henderson (2000).

\section{Results}

Food habits of rhino:

(a) Natural plants: The Great Indian One-horned Rhinoceros consumed 32 naturally occurring plant species - 15 grasses, four shrubs, eight trees and five aquatic hydrophytes (Table 1). Out of these plants, 21 species were terrestrial and 11 were aquatic. During the dry season, about $90 \%$ of rhino food constituted Hemarthria compressa, Arundo donax, Phragmites karka, Cerex rubro-brumee etc. Other short grasses such as Cynodon dactylon, Andropogon ssp., Andropogon aciculatus and Cenchrus ciliaris tender and young shoots and twigs of Saccharum spontaneum, Lagerstroemia flosreginae, etc. were consumed to a limited extent.

(b) Cultivated food items: Rhinos in Pobitora also consumed 11 different cultivated food plants (Table 2), which grow in the periphery of the sanctuary during dry (winter) and premonsoon seasons. Plants such as Ricinus communis, Oryza sativa, Solanum melongena, Lycopersicon esculentum, Solanum tuberosum, Cucumis sativus, Luffa acutangula, Luffa cylindrica, Cucurbita moschata, Brassica nigra and Ipomoea batatas were common in and around the boundary of the study area. The rhinos frequently raided the village farmlands for food.

\section{Status of food plant species}

Grass species recorded in high density are Cynodon dactylon $\left(167.5 / \mathrm{m}^{2}\right)$, Hemarthria compressa $\left(73.75 / \mathrm{m}^{2}\right)$, Vetiveria zizanioides $\left(56 / \mathrm{m}^{2}\right)$, Saccharum ravannae $\left(51.5 / \mathrm{m}^{2}\right)$, Pharagmites karka $\left(50.75 / \mathrm{m}^{2}\right)$, Leersia hexandra $\left(46.75 / \mathrm{m}^{2}\right)$, Hymenachne pseudointerrupta $\left(40 / \mathrm{m}^{2}\right)$ and Water Hyacinth-Eichhornia crassipes $\left(35 / \mathrm{m}^{2}\right)$ (Table $\left.3 \& 4\right)$.

The Cynodon dactylon, Hemarthria compressa and Imperata cylindrica (sprouting stages) are the most commonly used food plants of the rhinos at PWS. Entire portion of these plants above the ground level was consumed. Only small twigs and younger leaves of Vetiveria zizanioides, Saccharum ravannae, Phragmites karka, Imperata cylindrica, Pollinia ciliata, Saccharum spontaneum, Costus speciosus, Alpinia allughas, Ziziphus jujuba, Lagerstroemia flosreginae, Sachumannianthus dichotomus and Arundo donax were consumed.

According to the mahouts of Pobitora, during high-flood, rhinos consume the leaves of Ficus religiosa, Schelristechya fuesche, Syzygium fruticosum, Fleminigia ssp., Bambusa tulda and Thysanolaena agrostis. Rhinos swim out to eat grass tops sticking out of water. The top of these tall grasses and reeds are not soft and not preferred under normal conditions. Rhinos and Water Buffaloes go under water and eat the submerged grasses too. When they surface they have mouthfuls of vegetation, chew and swallow above the water level. Rhinos sometimes enter paddy fields around the sanctuary and eat sprouting plants. Observations on feeding by night-raiding rhinos were not made.

\section{Discussion}

Grasses play a major role in the food requirements of the Indian Rhino to maintain its body weight of over $200 \mathrm{~kg}$. It needs approximately $150 \mathrm{~kg}$ of fodder per day (Dutta 1991). The Indian Rhinoceros grazes during early morning, late afternoon and through the night. During heavy floods and dry 
season, rhinos consume Water Hyacinth (Eichhornia crassipes) that occasionally causes purging. Rhinos normally eat the tender sprouts of tree species and sprouting stages of tall grasses such as Saccharum ravannae, Phragmites karka and Arundo donax. Our Observations are similar to Dutta (1991). Food intake, about 90\% comes from Hemarthria compressa, Arundo donax, Pharagmites karka, Cerex-rubro brumee during the dry season as these species occur in the habitat in abundance at this time. Rhinos eat floating and creeping plants species such as Ipomea aquatica, Enhydra fluctuans, Pistia stratiotes, Lemna perpusilla, Eichhornia crassipes, also, which grow in marshy areas. Food habits of rhinos differ locality-wise. Verbanacious shrubs are rejected as food in PWS, but in Kaziranga they eat the apical parts of verbanacious shrub, Lippia geminata.

Although grasses constitute the favorite fodder, the Indian Rhino is not averse to eating occasional delicacies like brinjal, capsicum and tomato; they avoid legumes like peas. During the season when food is plenty, rhinos do not eat bushy vegetation even if the saplings are invitingly young and tender. Within the surroundings of permanent forest camps inside a protected area, very often discarded mature seeds attached to parts of vegetables such as gourd, pumpkin etc. grow to new plants; such plants seem to be relished by the rhinos (Dutta 1991, Vigne \& Martin 1994). During short periods of highflood, when there is food scarcity, rhinos generally congregate on high land where limited number of natural plants other than grasses and herbs are available. At this time the rhinos are observed to eat the bark of trees, cane, leaves of Flemingia sp. and Albizzia sp. (Dutta 1991). During the time of food scarcity, rhinos eat whatever vegetation is available, and local forest guards report that Ficus religiosa, Zizyphus jujuba, Lagerstroemia flosreganae are also eaten. The animal is known to eat pulses, mustard plants, potatoes, gourd and other vegetables (Dutta 1991; Villagers pers. inter. 2001).

Monsoon flood regularly affects the distribution pattern of rhino food-plant species in the sanctuary every year (Forest Department Officials pers. comm. 2001). The other major problem of the rhinos at Pobitora is the invasion of grasslands by woodland species like Albizia procera. This serious threat needs to be controlled by uprooting the exotic alien species. Presently, poaching and encroaching are other major problems adding to scarcity of food plant species.

\section{Conservation problems and recommendation}

1. Grazing by 2500-3000 cattle every day is one of the major problems in PWS. This drives 20-25 rhinos every night to raid croplands as far as $7 \mathrm{~km}$ away in the adjacent villages.

2. Illegal collection of thatch grasses, firewood and fishing by people throughout the year.

3. Entire area gets inundated by high-flood during the monsoon and consequent silt deposit. The swamp areas and 'beels' are gradually becoming shallow. A few highland platforms need to be created to protect the rhino population during flood.

In view of the incremental rise in rhino population density, it may become necessary to increase the cover area of PWS, where the highest rhino density in relation to total area is noted. Regular conflicts between the immigrant ethnic groups and forest officials, have to be resolved in the interest of rhino conservation, by joint efforts of people and the government.

\section{REFERENCES}

Arumugam, N. (1998). Concepts of Ecology (Environmental Biology). Saras Publication, $421 \mathrm{pp}$.

Cooperrider, A.Y. (1986). Food Habits, pp.699-709. In: Coopperrider, A.Y., R.J. Boyel \& H.B. Stuart (eds.). Inventory and Monitoring of Wildlife Habitat. US Department of Interior, US Bureau of Land Management.

Dutta, A.K. (1991). Unicornis. The Great Indian One Horned Rhinoceros. Konark Publishers Pvt. Ltd. New Delhi (India), 143pp.

Foose, T.J. \& R. Emslie (1999). Overview of Status of Asian and African Rhino. Report on the regional meeting for India and Nepal of the IUCN/SSC, 39pp.

Holechek, J.L., M. Vavra \& R.D. Pieper (1982). Botanical composition determination of range herbivore diets: a review. Journal of Range Management 35: 309-315.

Islam, M.Z. \& A.R. Rahmani (2004). Important Bird Area in India, Priority Sites for Conservation. Indian Bird Conservation Network: Bombay Natural History Society and Birdlife International (UK), pls. xviii + 1133 pp.

Kanjilal, U.N. \& N.L. Bor (1940). Flora of Assam Vol: V. Gramineae. Government of Assam, Shillong, 480pp.

Kanjilal, U.N., P.C. Kanjilal \& A. Das (1934). Flora of Assam. Vol: 1 Part1. Liakshminarayan Prabasi press 120-2 Upper Circular Road, Calcutta, 184pp.

Kanjilal, U.N., P.C. Kanjilal, A. Das \& C. Purkayastha (1936). Flora of Assam. Vol: I, Part-II. Liakshminarayan Prabasi Press, 120-2, Upper Circular Road, Calcutta, 386pp.

Kanjilal, U.N., P.C. Kanjilal \& A. Das (1938). Flora of Assam. Vol: III Part-1. Liakshminarayan Prabasi Press 120-2, Upper Circular Road, Calcutta, 480pp.

Kanjilal, U.N., P.C. Kanjilal, A. Das \& R.N. De (1939). Flora of Assam. Vol: III, Part-2. Liakshminarayan Prabasi Press 120-2, Upper Circular Road, Calcutta, 578pp.

Kanjilal, U.N. (1940). Flora of Assam. Vol: IV, Liakshminarayan Prabasi Press, 120-2, Upper Circular Road, Calcutta, 136pp.

Korschgen, L.J. (1980). Procedures for food-habit analyses, pp. 113127. In: Schemnitz, S.D. (ed). Wildlife Management Techniques Manual 4th Edition. Wildlife Society, Washington, DC, 686pp.

Krebs, C.J. (1985). Ecology: The Experimental Analysis of Distribution and Abundance. Harper and Row, New York, 900pp.

Neff, D.J. (1974). Forage preferences of trained Mule Deer on the Beaver Creek watershed. Arizona Game and Fish Department, Special Report No-4, $61 \mathrm{pp}$.

Riney, T. (1982). Study and Management of Large Mammals. John Wiley and Sons, New York, NY., 552pp.

Southwood, T.R.E. \& P.A. Henderson (2000). Ecological Methods. $3^{\text {rd }}$ Edition. Blackwell Science Ltd. London, 575pp.

Talukdar, B.K. (1996). Diversity of waterbirds in Pabitora Wildlife Sanctuary. Pavo 34: 17-21

Vigne, L. \& E.B. Martin (1994). The greater one horned rhinoceros of Assam is threatened by poachers. Pachyderm 18: 28-43.

Wallmo, O.C., R.B. Gill, L.H. Carpenter \& D.W. Reichert (1973). Accuracy of field estimates of deer food habits. Journal of Wildlife Management 37: 556-562

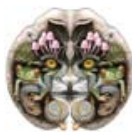

